\title{
PERUBAHAN PERILAKU MASYARAKAT MELALUI PENYULUHAN DAN PEMBUATAN CTPS DI DESA TANAH PUTIH
}

\author{
Sunarti Hanapi ${ }^{1,}$ Moh. Rivandi Dengo ${ }^{2,}$ Desri landa singal ${ }^{3,}$ Irmawati Suma4 \\ Fakultas Kesehatan Masyarakat Universitas Gorontaloi; \\ email: sunarti82hanapi@gmail.com \\ Fakultas Kesehatan Masyarakat Universitas Gorontalo ${ }^{2 ;}$ \\ email:moh.rivandidengo@gmail.com \\ Fakultas Kesehatan Masyarakat Universitas Gorontal ${ }^{3}$ \\ email: Desrilanda@gmail.com \\ Fakultas Kesehatan Masyarakat Universitas Gorontalo ${ }^{4}$ \\ email:irmawatisuma3@gmail.com
}

\begin{abstract}
Abstrak
Mencuci tangan pakai sabun adalah salah satu upaya pencegahan melalui tindakan sanitasi dengan membersihkan tangan dan jari jemari menggunakan air dan sabun. Tangan manusia seringkali menjadi agen yang membawa kuman daan menyebabkan patogen berpindah dari satu orang atau dari alam ke orang lain melalui kontak langsung atau tidak langsung. Berdasarkan hasil survey Desa Tanah Putih merupakan sebuah wilayah yang berada di Kecamatan Dulupi, Kabupaten Boalemo, dengan batas Desa Polohungo di sebelah timur, Desa Pangi di sebelah barat dan Desa Tangga jaya sebelah utara. Tanah Putih mempunyai wilayah dengan pemukiman dengan luas o $\mathrm{Ha}$, perkebunan dengan luas $2 \mathrm{Ha}$, dan hutan seluas o $\mathrm{Ha}$, kepadatan penduduk di wilayah Desa Tanah Putih yang tergolong cukup bisa menyebabkan potensi penyakit menular sangat besar. Berdasarkan hasil pendataan pada pengalaman belajar lapangan I kepemilikan Tempat Cuci Tangan yang paling banyak Terdistribusi yaitu pada Dusun 2 sebanyak $45(27,3 \%)$ dengan kategori Tidak Tersedia sabun dan yang paling sedikit terdapat di Dusun 3 sebanyak $2(1,2 \%)$ dengan kategori Tidak memiliki tempat cuci tangan. Tujuan pengabdian ini dilakukan untuk meningkatkan pengetahuan dan perubahan perilaku masyarakat tentang pentingnya CTPS untuk hidup bersih dan sehat. Kegiatan pengabdian pada masyarakat ini bertujuan untuk menerapkan pola hidup sehat masyarakat Desa Tanah Putih, Kecamatan Dulupi,Kabupaten Boalemo. Hasil yang diperoleh dari pengabdian kepada masyarakat ini adalah memberikan informasi pada masyarakat Desa Tanah Putih tentang pentingnya mencuci tangan pakai sabun untuk pencegahan dari berbagai penyakit. Serta kami memberikan informasi tentang pembuatan tempat cuci tangan yang bisa diolah dari barang bekas, contohnya galon air minum, gelong minyak, ember dan masih banyak lagi barang bekas yang bisa digunakan untuk pembuatan Tempat cuci tangan.
\end{abstract}

Kata Kunci: Sosialisasi, Kesehatan Masyarakat, Cuci Tangan

\section{Abstract}

Washing hands with soap is one of the prevention efforts through sanitation measures by cleaning hands and fingers using water and soap. Human hands are often agents that carry germs 
E-ISSN: 2776-3331

Vol. 1, No. 2, pp. 108-118

November, 2021

and cause pathogens to pass from one person or from nature to another through direct or indirect contact. Based on the survey results, Tanah Putih Village is an area located in Dulupi District, Boalemo Regency, with the boundaries of Polohungo Village in the east, Pangi Village in the west and Tangga Jaya Village in the north. Tanah Putih has an area with settlements with an area of 2,00o ha, plantations with an area of 2 ha, and a forest covering an area of 2,00o ha, the population density in the Tanah Putih Village area which is quite large can cause a very large potential for infectious diseases. Based on the results of data collection on the field learning experience I, the ownership of the handwashing area was the most distributed, namely in Hamlet 2 as many as 45 (27.3\%) with the category of No Soap Available and the least being in Hamlet 3 as much as 2 (1.2\%) with category Does not have a hand washing station. The purpose of this service is to increase knowledge and change people's behavior about the importance of CTPS for clean and healthy living. This community service activity aims to implement a healthy lifestyle for the people of Tanah Putih Village, Dulupi District, Boalemo Regency. The results obtained from this community service are to provide information to the people of Tanah Putih Village about the importance of washing hands with soap for the prevention of various diseases. And we provide information about making hand washing stations that can be processed from used goods, for example gallons of drinking water, oil jugs, buckets and many other used items that can be used for making hand washing stations.

Keywords: Sosialization, Public Health, washing hand

\section{PENDAHULUAN}

Mencuci tangan pakai sabun adalah salah satu upaya pencegahan melalui tindakan sanitasi dengan membersihkan tangan dan jari jemari menggunakan air dan sabun. Tangan manusia seringkali menjadi agen yang membawa kuman daan menyebabkan patogen berpindah dari satu orang atau dari alam ke orang lain melalui kontak langsung atau tidak langsung. (Mustikawati, I. S. 2017). Mencuci tangan bermanfaat agar tangan menjadi bersih dan dapat membunuh mikroorganisme yang ada di tangan, dan telah dibuktikan dari study terdahulu dapat mencegah penyakit infeksi di masyarakat seperti diare, Infeksi Saluran Pernafasan Atas (ISPA) dan flu burung serta covid-19, walaupun demikian pentingnya perilaku cuci tangan pakai sabun (CTPS) untuk mencegah penyakit - penyakit menular tampaknya masih belum dimengerti masyarakat luas termasuk santri di pondok pesantren serta masih belum banyak dilakukan dalam kehidupan seharihari (Panduan CTPS Depkes RI, 2013 dalam Asda.P 2020).

Mencuci tangan memakai sabun sangat penting sebagai salah satu mencegah terjadinya diare, kebiasaan mencuci tangan diterapkan setelah buang air besar, setelah menceboki bayi dan balita, sebelum makan serta sebelum menyiapkan makanan. Masyarakat akan mampu meningkatkan pengetahuan hidup sehat dimanapun mereka berada jika mereka sadar, termotivasi dan di dukung dengan adanya informasi serta sarana dan prasarana kesehatan. (Suharti, S. 2020). CTPS telah terbukti efektif sebagai bentuk pencegahan Covid-19. Berbagai sarana mencuci tangan telah dikembangkan dan disosialisasikan pada masyarakat sebagai respon terhadap Covid-19. Beberapa di antaranya adalah fasilitas cuci tangan berupa ember yang telah dilengkapi dengan keran sehingga memudahkan masyarakat untuk mencuci tangan (Risfianty \& Indrawati, dalam Dewantoro,dkk.2020). 
Promosi kesehatan adalah suatu upaya yang tidak hanya menekankan perubahan pada pengetahuan, sikap, dan tindakan kesehatan, tetapi juga menciptakan perubahan pada lingkungan baik secara fi sik maupun non fisik melalui strategi advokasi, bina suasana pemberdayaan masyarakat, dan peran kemitraan (Kholid, 2014 dalam Trijayanti 2011).

Berdasarkan hasil survey desa tanah putih merupakan sebuah wilayah yang berada di kecamatan dulupi, Kabupaten boalemo, dengan batas desa polohungo di sebelah timur, desa pangi di sebelah barat dan deas tangga jaya sebelah utara. Tanah puti mempunyai wilah dengan pemukiman dengan luas o Ha, perkebunan dengan luas $2 \mathrm{Ha}$, dan hutan seluas o $\mathrm{Ha}$, kepadatan penduduk di wilayah desa tanah putihyang tergolong cukup bisa menyebabkan potensi penyakit menular sangat besar

Berdasarkan data yang di peroleh dari hasil laporan kegiatan pendataan mahasiswa PBL I diperolehan data kepemilikan Tempat Cuci Tangan yang paling banyak Terdistribusi yaitu pada Dusun 2 sebanyak 45 (27,3\%) dengan kategori Tidak Tersedia sabun dan yang paling sedikit terdapat di Dusun 3 sebanyak 2 (1,2\%) dengan kategori Tidak memiliki tempat cuci tangan.

Tujuan pengabdian ini dilakukan untuk meningkatkan pengetahuan dan perubahan perilaku masyarakat tentang pentingnya CTPS untuk hidup bersih dan sehat

\section{METODE}

Kegiatan pengabdian pada masyarakat ini bertujuan untuk menerapkan pola hidup sehat masyarakat desa tanah putih, kecamatan Dulupi,kabupaten bualemo. Ada beberapa langkah yang di lakuakandalam kegiatan ini yakni:

Metode yang digunakan adalah kegiatan penyuluhan kepada masyarakat desa tanah putih dengan cara:

1. Pre-even. Dalam pre-even ini mahasiswa membagikan kuesioner yang berisi tentang pengetahuan serta sikap dalam kepemilikan tempat cici tanagan.

2. Even. Pemberian materi kepada masyarakat mengenai manfaat dan tujuan pemanfaatan tempat cuci tanagan, pada saat pemberian materi terdapat diskusi serta Tanya jawab tentang

3. Post-even. Pembagian kuesioner yanga sama dengan sebelumnya tujuannya agar mahasiswa sapat menilai kembali apakah terdapat peningkatan pengetahuan masyarakat atau tidak.

4. Membuat tempat cuci tanagn percontohan berbahan dasar kayu(lata) dan gelong bekas.

5. Melakukan penempatan tenpat cuci tanagan percontohan di deasa tanah putih khususnya di dusun 2.

Kegiatan penyuluhan cuci tangan pakai sabun pada masyarakat Desa Tanah Putih Kecamatan Dulupi Kabupaten Boalemo ini diadakan pada hari selasa 14 september 2021 bertempat di Aula Kantor desa Tanah Putih Kecamatan Dulupi. Kegiatan ini dimulai dari Pukul 14:0o WITA - 16:30 WITA 


\section{HASIL DAN PEMBAHASAN}

Bentuk partisipasi maysrakat dalam pelaksanaan kegiatan ini cukup aktif dan menyambut baik program penyuluhan tentang peningkatan pengetahuan dan perilaku masyarakat tentang CTPS. Kegiatan ini dimulai dengan pemberitahuan terlebih dahulu kepada kepala Desa Tanah Putih guna mendapatkan persetujuan dari Kepala Desa untuk melaksanakan kegiatan penyuluhan cuci tangan pakai sabun serta dirangkaikan dengan pembagian kusioner kepada masyarakat Desa Tanah Putih. Tapi Hal ini dilakukan 4 hari sebelum kegiatan dilaksanakan. Kegiatan yang di rencanakan dalam bentuk kegiatan Fisik dan Non fisik .

\section{Intervensi Non-Fisik}

\section{a. Tahap Awal}

Kegiatan ini dilaksanakan setelah mendapatkan ijin dari kepala Desa Tanah Putih Tahap awal ini dilakukan dengan pembagian kusioner yang berisi tentang pengetahuan serta sikap dalam kepemilikan tempat cuci tangan kepada masyarakat Desa Tanah Putih. Kegiatan ini dilaksanakan sebelum penyuluhan dimulai.

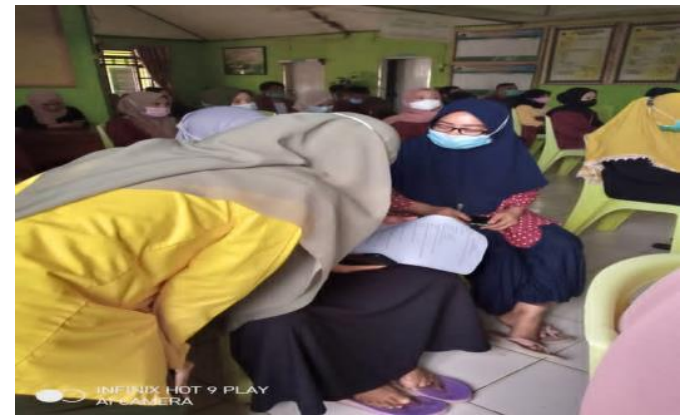

\section{Gambar 1. Pengisian Kusioner CTPS Sebelum Penyuluhan Desa Tanah Putih}

\section{b. Tahap Kegiatan Pelaksanaan}

Pada kegiatan pelaksanaan dilakukan penyuluhan kesehatan tentang ctps dan pembuatan ctps percontohan pada masyarakat desa tanah putih. Pada kegiatan penyuluhan ini kami memberikan materi tentang pentingnya mencuci tangan pakai sabun. Pada kegiatan penyuluhan yang ditekankan oleh pemateri adalah cara mencuci tangan dengan sabun serta mempraktekkannya. Hal ini dilakukan karena masih ada masyarakat yang belum memahami 6 langkah cara mencuci tangan dengan baik dan benar.

Adapun 6 langkah dalam mencuci tangan yakni: 1) Tuang cairan handrub (antiseptik berbasis alkohol) pada telapak tangan kemudian usap dan gosok kedua telapak tangan secara lembut dengan arah memutar. 2) Usap dan gosok juga kedua punggung tangan secara bergantian, 3) Gosok sela-sela jari tangan hingga bersih, 4) Bersihkan ujung jari secara bergantian dengan posisi saling mengunci, 5) Gosok dan putar kedua ibu jari secara bergantian, 6) Letakkan ujung jari ke telapak tangan kemudian gosok perlahan. Enam Langkah ini adalah cara mencuci tangan yang baik dan benar dan wajib dipraktekkan oleh masyarakat di Desa Tanah Putih. 


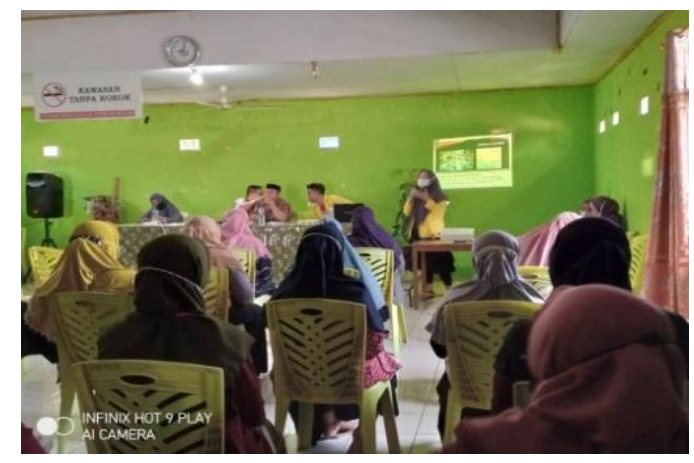

Gambar 2. Penyuluhan tentang pentingnya mencuci tangan pakai sabun Di Desa Tanah Putih

Kegiatan penyuluhan tentang pentingnya cuci tangan pakai sabun untuk menghindari penyakit serta memutus rantai penyebaran covid-19. Pada kegiatan penyuluhan tersebut kami menjelaskan kepada masyarakat tentang pentingnya mencuci tangan pakai sabun agar masyarakat bisa menjaga kebersihan diri dan dapat terhindar dari penyakit.

Lingkungan yang sehat akan membantu masyarakat yang tinggal dalam lingkungan tersebuat merasa nyaman, tenang dan bahagia sehingga dapat menikmati hidup. Tubuh yang sehat dapat diperoleh dengan mengkonsumsi makanan yang bersih dan sehat serta lengkap akan gizi, selain itu dengan menerapkan pola hidup bersih akan menguatkan system imun tubuh.

\section{c. Tahap Evaluasi}

Tahap evaluasi dilakukan dengan pembagian kembali kusioner terkait pentingnya tempat cuci tangan, manfaat mencuci tangan pakai sabun serta bahaya perilaku tidak mencuci tangan pakai sabun, yang sudah kami lakukan penyuluhan kepada masyarakat Desa Tanah Putih.

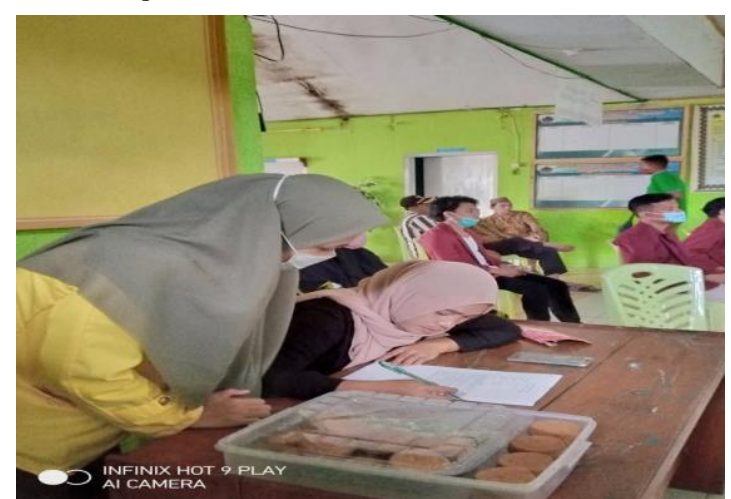

Gambar 3. Pengisian kembali kusioner Setelah melakukan penyuluhan Tentang CTPS Di Desa Tanah Putih. 


\section{d. Tahap Penutupan Kegiatan}

Pukul 16.30 WITA acara penutupan kegiatan dengan melakukan dokumentasi bersama apparat Desa Tanah Putih
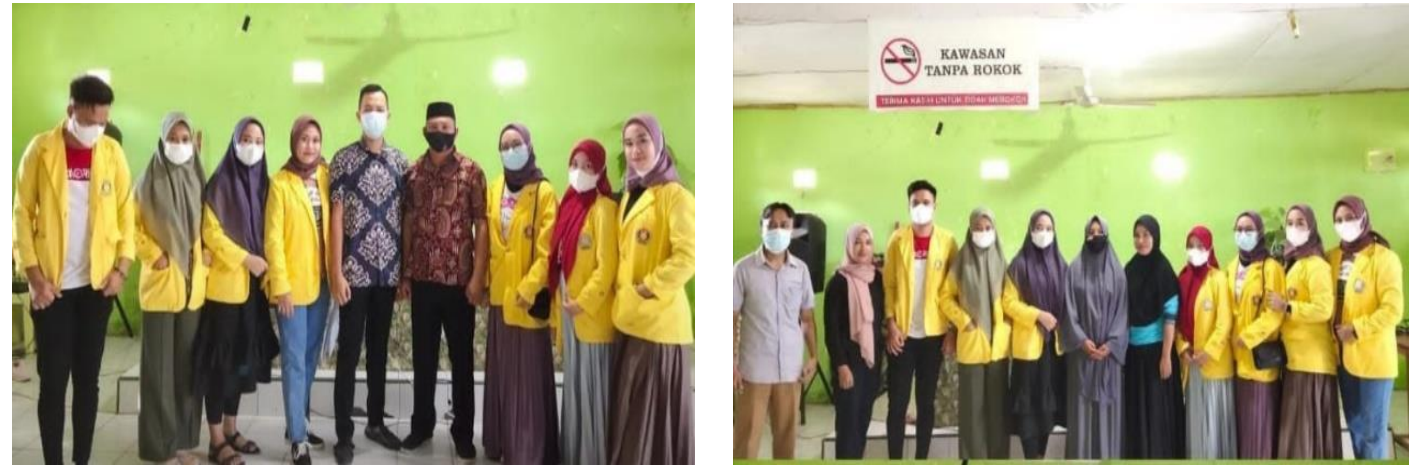

Gambar 4. Dokumentasi Bersama Aparat Desa Tanah Putih Kabupaten Boalemo

Hasil yang diperoleh dari pengabdian kepada masyarakat ini adalah memberikan informasi pada masyarakat Desa Tanah Putih tentang pentingnya mencuci tangan pakai sabun untuk pencegahan dari berbagai penyakit. Serta kami memberikan informasi tentang pembuatan tempat cuci tangan yang bisa diolah dari barang bekas, contohnya galon air minum, gelong minyak, ember dan masih banyak lagi barang bekas yang bisa digunakan untuk pembuatan Tempat cuci tangan. Dengan memberikan informasi tersebut diharapkan Tempat cuci tangan ini bisa diterapkan di rumah-rumah masyarakat desa Tanah Putih.

\section{Hasil Kegiatan}

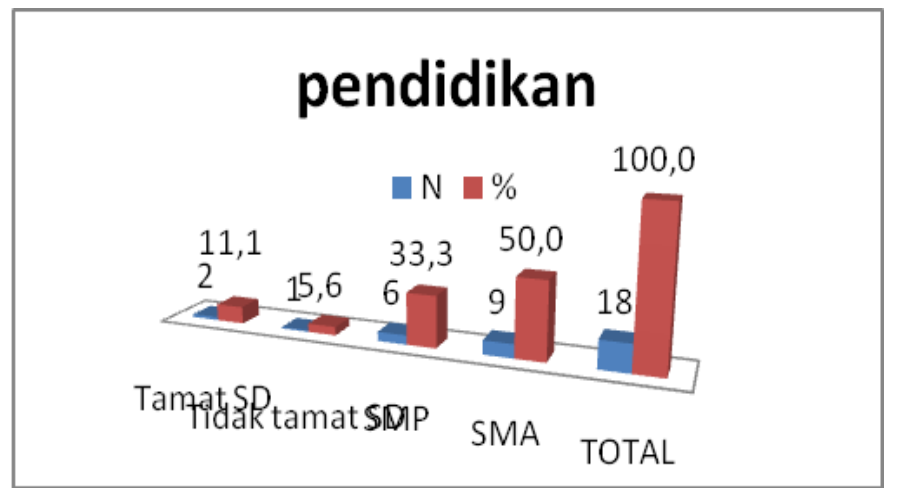

\section{Grafik 1. Distribusi Pendidikan Desa Tanah Putih Kecamatan Dulupi Kabupaten Boalemo}

Pada grafik 1 distribusi pendidikan dari 18 orang yang mengisi kusioner yang paling banyak terdistribusi yaitu pada pendidikan SMA dengan jumlah 10 orang $(55,6 \%)$ sedangkan yang paling sedikit terdistribusi yaitu pada tingkat tidak sekolah 1 orang $(5,6 \%)$ 


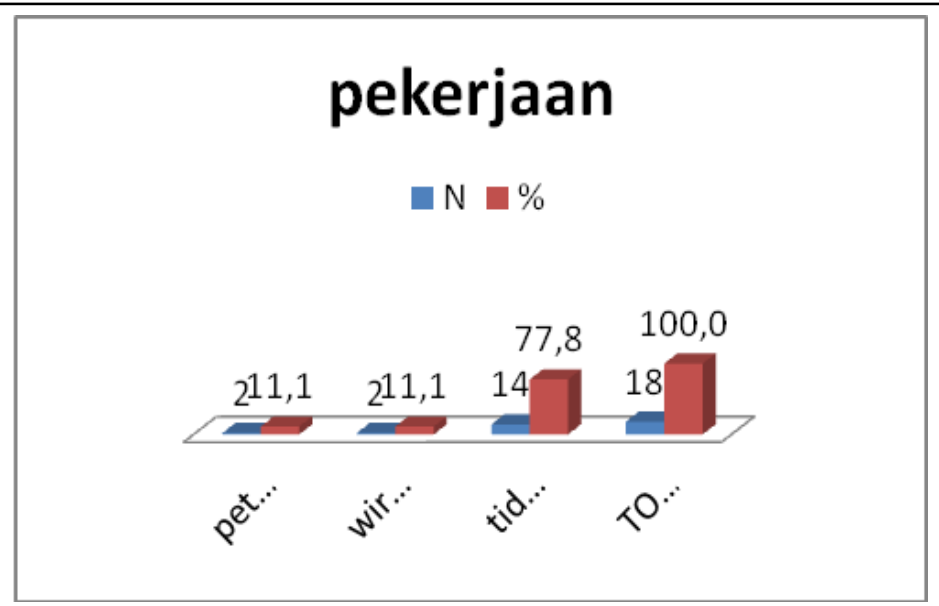

\section{Grafik 2. Distribusi Pekerjaan Desa Tanah Putih Kecamatan Dulupi} Kabupaten Boalemo

Pada grafik 2 distribusi pekerjaan dari 18 orang yang mengisi kusioner yang paling banyak terdistribusi yaitu pada orang tidak memiliki pekerjaan dengan jumlah 14 orang $(77,8 \%)$ sedangkan yang paling sedikit terdistribusi yaitu pada petani 2 orang $(11,1 \%)$.

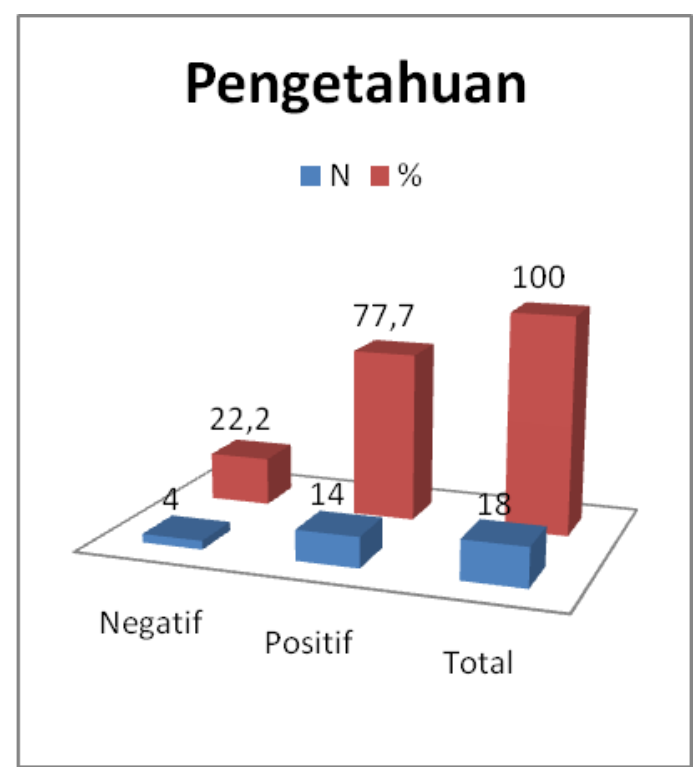

Grafik 3. Distribusi pengetahuan Sebelum penyuluhan CTPS Di Desa Tanah

\section{Putih Kabupaten Boalemo}

Pada grafik 3 distribusi pengetahuan sebelum penyuluhan CTPS dari 18 orang yang terdistribusi paling banyak yaitu yang mengisi dengan skor >50 yaitu sebanyak 15 orang. 


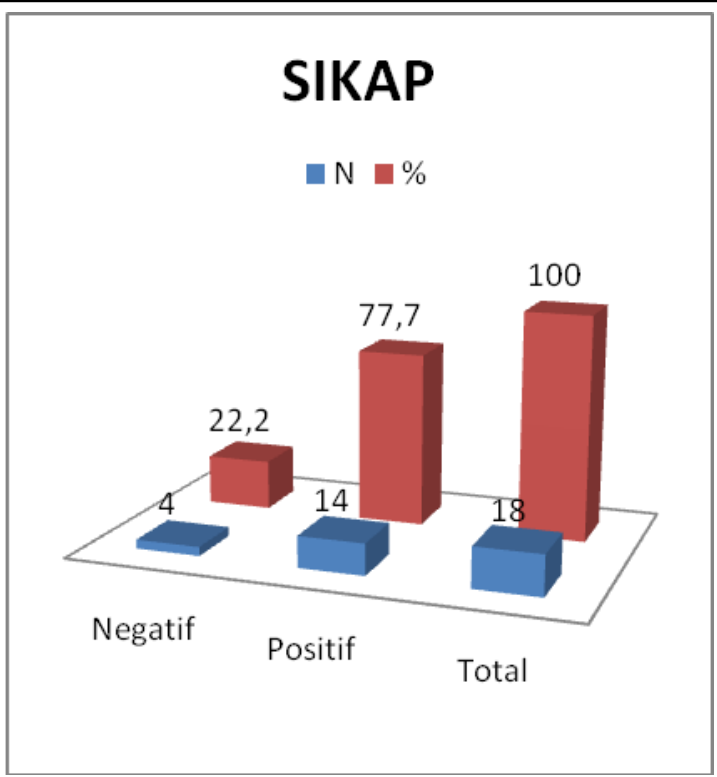

Grafik 4. Distribusi Sikap sebelum penyuluhan CTPS Di Desa Tanah Putih Kabupaten Boalemo

Pada grafik 4 distribusi sikap sebelum penyuluhan tentang CTPS dari 18 orang terdistribusi yang paling banyak mengisi yaitu 14 orang $(77,7 \%)$

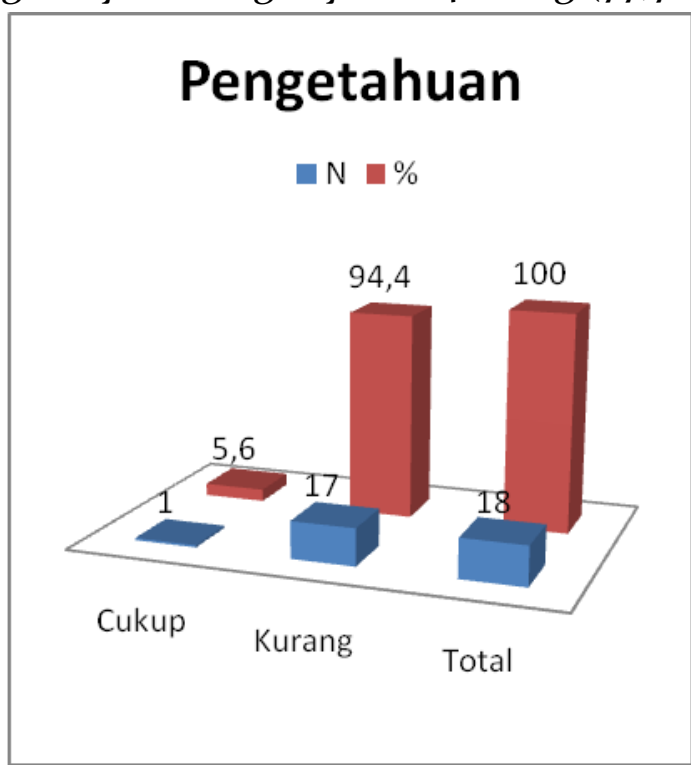

Grafik 5. Distribusi pengetahuan Sesudah Penyuluhan CTPS desa Tanah

\section{Putih Kabupaten Boalemo}

Pada grafik 5. Distribusi pengetahuan sesudah penyuluhan CTPS dari 18 orang terdistribusi paling banyak yaitu yang mengisi dengan skor $>50$ yaitu sebanyak 17 orang $(83,3 \%)$ 


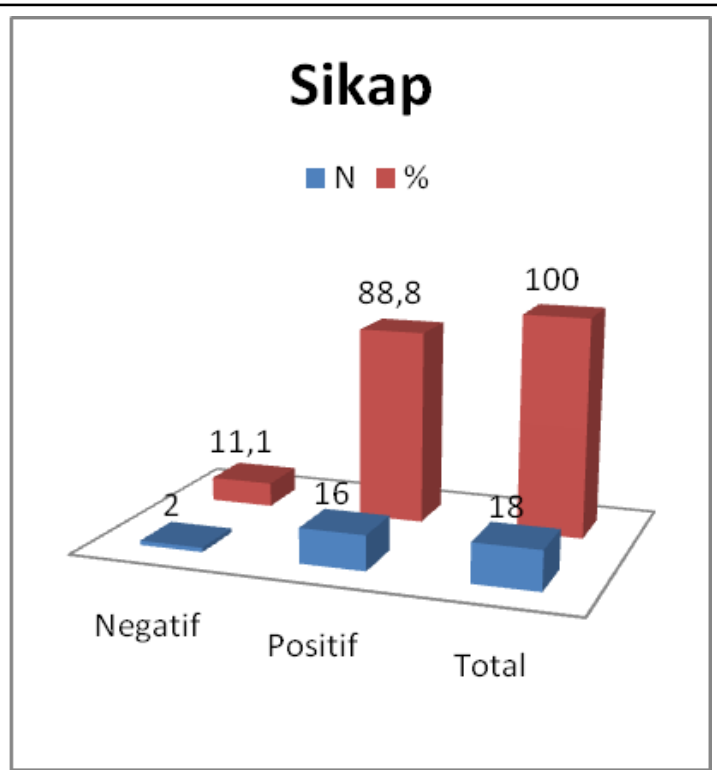

\section{Grafik 6. Distribusi Sikap Sesudah Penyuluhan CTPS Desa Tanah Putih Kabupaten Boalemo}

Pada grafik 6 distribusi sikap sesudah penyuluhan CTPS dari 18 orang terdistribusi yang memiliki nilai tinggi ada 16 orang $(88,8 \%)$.

\section{Intervensi Fisik}

Setelah pelaksanan kegiatan penyuluhan, pada hari Rabu tanggal 15 september 2021 kami melakukan kegiatan pembuatan tempat cuci tangan percontohan di halaman rumah warga desa tanah putih.

\section{Tahap Pembuatan CTPS Percontohan}

Pada kegiatan ini kami membuat tempat cuci tangan percontohan. Dalam pembuatan tempat cuci tangan ini kami dibantu oleh rema muda Desa Tanah Putih.

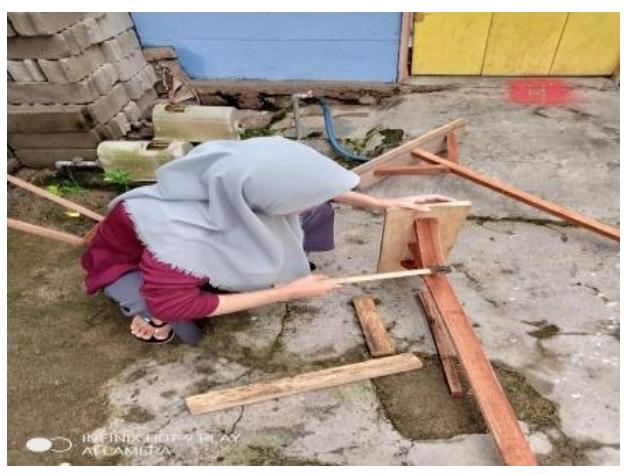

\section{Gambar 1. Pembuatan CTPS Percontohan Di Desa Tanah Putih}

Pembuatan tempat cuci tangan ini kami membuat 2 buah tempat cuci tangan, masing-masing tempat cuci tangan ini nantinya akan diletakkan di halaman rumah Kepala Dusun II dan satunya lagi diletakkan di halaman Mesjid dusun II. 


\section{Tahap penyerahan Tempat Cuci Tangan Percontohan}

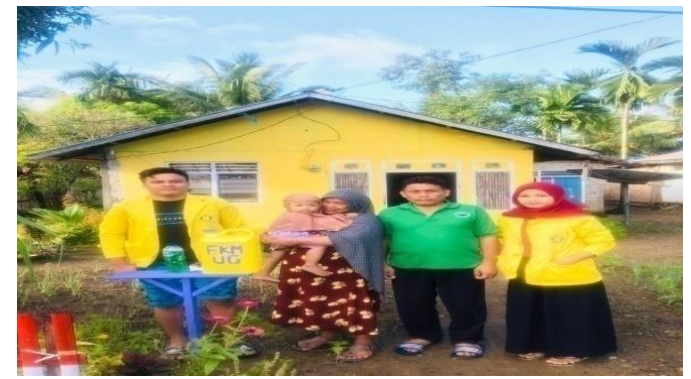

\section{Gambar 2. Penyerahan Tempat cuci tangan percontohan Kepada Kepala}

\section{Dusun II Desa Tanah Putih}

Gambar 2 diatas menunjukan kegiatan penyerahan tempat cuci tangan percontohan. Pemberian tempat cuci tangan ini disambut antusias oleh Kepala Dusun II Desa tanah putih. Tempat cuci tangan percontohan ini diharapkan agar warga masyarakat desa Tanah Putih bisa membuat tempat cuci tangan sendiri dirumah serta membiasakan masyarakat untuk hidup sehat dan bersih. Kegiatan mencucitangan merupakan kegiatan yang belum menjadi kebiasaan di masyarakat, setelah munculnya pandemic covid-19. Kegiatan cuci tangan mengunakan sabun merupakan salah satu new normal yang harus dilakukan oleh seluruh lapisan masyarakat dimanapun dan kapan pun. (Risfianty DK, Indrawati.2020). Cuci tangan pakai sabun sebagai upaya preventif dalam melindungi diri dari berbagai penyakit menular. Cuci tangan menggunakan sabun dapat kita lakukan pada waktu-waktu berikut: sebelum menyiapkan makanan, sebelum dan sesudah makan, setelah BAK dan BAB, setelah membuang ingus, setelah membuang dan atau menangani sampah, kemudian setelah bermain/memberi makan/memegang hewan, serta setelah batuk atau bersin pada tangan kita.

Cuci tangan pakai sabun yang dipraktikkan secara tepat dan benar merupakan cara termudah dan efektif untuk mencegah berjangkitnya penyakit. Mencuci tangan dengan air dan sabun dapat lebih efektif menghilangkan kotoran dan debu secara mekanis dari permukaan kulit dan secara bermakna mengurangi jumlah mikroorganisme penyebab penyakit seperti virus, bakteri dan parasit lainnya pada kedua tangan. Mencuci tangan dengan menggunakan air dan sabun dapat lebih efektif membersihkan kotoran dan telur cacing yang menempel pada permukaan kulit, kuku dan jari-jari pada kedua tangan dapat lebih efektif membersihkan kotoran dan telur cacing yang menempel pada permukaan kulit, kuku dan jari-jari pada kedua tangan.

\section{KESIMPULAN}

Mencuci tangan merupakan proses pembuangan kotoran dan debu secara mekanis dari kedua belah tangan dengan memakai sabun dan air. Mencuci tangan juga dapat menghilangkan sejumlah besar virus yang menjadi penyebab berbagai penyakit, terutama penyakit yang menyerang saluran cerna, seperti diare dan saluran nafas seperti influenza. 
Hasil yang diperoleh dari pengabdian kepada masyarakat ini adalah memberikan informasi pada masyarakat Desa Tanah Putih tentang pentingnya mencuci tangan pakai sabun untuk pencegahan dari berbagai penyakit. Serta kami memberikan informasi tentang pembuatan tempat cuci tangan yang bisa diolah dari barang bekas, contohnya galon air minum, gelong minyak, ember dan masih banyak lagi barang bekas yang bisa digunakan untuk pembuatan Tempat cuci tangan.

Dari kegiatan ini memberikan edukasi kepada masyarakat desa Tanah Putih tentang pentingnya mencuci tangan pakai sabun dan air mengalir untuk mengindari penyakit dengan memberikan fasilitas tempat cuci tangan percontohan agar masyarakat bisa membuat tempat cuci tangan sendiri.

\section{UCAPAN TERIMA KASIH}

Alhamdulillah puji syukur kepada Allah swt, karena kehendak dan ridha-Nya kami dapat menyelesaikan jurnal ini. kami sadari jurnal ini tidak akan selesai tanpa doa, dukungan dan dorongan dari berbagai pihak. Terima kasih kepada masyarakat dan juga aparat desa tanah putih karena telah membantu kegiatan PBL II ini berjalan dengan lancar.

\section{REFERENSI}

Asda, P., \& Sekarwati, N. (2020). Perilaku Cuci Tangan Pakai Sabun (Ctps) Dan Kejadian Penyakit Infeksi Dalam Keluarga Di Wilayah Desa Donoharjo Kabupaten Sleman. Media Keperawatan: Politeknik Kesehatan Makassar, $11(1), \quad 1$. https://doi.org/10.32382/jmk.v11i1.1237

Dewantoro, G., Jody, I., Abdurrahman, I., Yansen, F., \& Setyawijaya, H. (2021). Rancang Bangun Alat Cuci Tangan Nirsentuh sebagai Sarana Edukasi dan Pencegahan Covid-19. Magistrorum et Scholarium: Jurnal Pengabdian Masyarakat, 1(2), 203-214. https://doi.org/10.24246/jms.vii22020p203-214

Mustikawati, I. S. (2017). Perilaku Cuci Tangan Pakai Sabun Studi Kualitatif pada IbuIbu di Kampung Nelayan Muara Angke Jakarta Utara; Studi Kualitatif. ARKESMAS (Arsip Kesehatan Masyarakat), 2(1), 115-125. https://doi.org/10.22236/arkesmas.v2i1.514

Risfianty, dwi kartika, \& Indrawati. (2020). Pemberdayaan Kesehatan Masyarakat Melalui Pengadaan Fasilitas Cuci Tangan pada Masa Pandemi Covid-19 di Masjid dan Mushala Dusun Montong Are Tengah. Jurnal Hasil Pengabdian $\mathcal{E}$ Pemberdayaan Kepada Masyarakat, 1(2), 94-99.

Suharti, S. (2020). Pendidikan Kesehatan Tentang 6 Langkah Cuci Tangan di PAUD Sayap Ibu Bandar Lampung. ANDASIH Jurnal Pengabdian Kepada Masyarakat, 1(2), $1-6$.

Trijayanti, D. A. K. L. (2019). Perilaku Tentang Cuci Tangan Pakai Sabun Di Madrasah Ibtidaiyah Taswirul Afkar. Jurnal PROMKES, $7(1), \quad 46$. https://doi.org/10.20473/jpk.v7.i1.2019.46-55 